\title{
Crowdfunding Adoption in Benin: Influencing Factors and Recommendations towards an Adapted Model
}

\section{Oloutchègoun Josias Lawrence Adjakou}

School of Economics and Management, Chongqing Jiaotong University, Chongqing, China

Email: josiasadjakou@gmail.com

How to cite this paper: Adjakou, O. J. L. (2021). Crowdfunding Adoption in Benin: Influencing Factors and Recommendations towards an Adapted Model. Open Journal of Business and Management, 9, 233-254. https://doi.org/10.4236/ojbm.2021.91013

Received: November 3, 2020

Accepted: January 17, 2021

Published: January 20, 2021

Copyright $\odot 2021$ by author(s) and Scientific Research Publishing Inc. This work is licensed under the Creative Commons Attribution International License (CC BY 4.0).

http://creativecommons.org/licenses/by/4.0/

\begin{abstract}
To face the problem of lack of funds, many developed countries have adopted the crowdfunding system. Despite the fact it has been established that the lack of proper funding institutions is a barrier to African countries' economic take-off, nothing sustainable has so far been done to tackle the issue. This paper aims to investigate factors influencing crowdfunding establishment as a substitute to formal financial organism in Benin republic, and give recommendations toward an adapted model to the country. To thoroughly conduct this study, both qualitative and quantitative methods are used. In Benin, some scholars in the domain of Finance and some people that have a good view of the current state of Benin economy were interviewed to know what they think about crowdfunding and the kind of models of crowdfunding they think may be adopted by Beninese. This helped to draw a final framework of the study, a questionnaire that served to collect first-hand data that were analyzed with SPSS (Statistical Package for Social Science) Statistics 26 through various tests. The study has revealed significantly positive correlation between each independent variable and the dependent variable which is the crowdfunding implementation. It also came out that to implement a sound and sustainable crowdfunding system particular care should be on a well-built regulatory framework, a well-managed technology transfer and a well-structured organizational environment. Notwithstanding the importance of all the variables, we came to notice that for people to accept and adopt crowdfunding as the study would like, some variables like "Payment System"; "Financial Consumer Protection"; "Security Trust"; "Cyber Security"; "Creditworthiness"; "Licensing”; "Complexity”; "Accessibility”; “Availability”; "Availability”; "Regulatory Framework" are of primordial importance, then follow the other variables. Suitable recommendations were given to a more customized and sustainable crowdfunding system.
\end{abstract}




\section{Keywords}

Crowdfunding, Entrepreneurship, Funding, Equity, Debt, FinTech, Remittance Transfer, Africa, Economic Development, Benin

\section{Introduction}

Kamunge and Tirimba asserted in their work that examined the causes impeding the results of SMEs in Africa that Small and Medium size enterprises help in reducing joblessness and provide revenues for about $80 \%$ of the world (Kamunge, Njeru, \& Tirimba, 2014). They went further stating SMEs contribution to Africa's GDP is up to $50 \%$ and represents over $90 \%$ of the continent's businesses. Micro Enterprises alone constitute $30 \%$ of the job market on the continent while medium and small sizes account respectively for $10 \%$ and $20 \%$ of the rate of employment (Fjose, Grünfeld, \& Green, 2010). In Kenya for instance, Mwarari and Kithae said SMEs brought work for $80 \%$ of the labor force in the country and accounted for more than $50 \%$ of jobs newly created. This made it up to $40 \%$ of the country's GDP (Kithae et al., 2012; Mwarari \& Ngugi, 2013). In West Africa; 95\% of the Nigerian manufacturing industry rely on the SMEs and this latter amount to $70 \%$ of their industrial work (Kauffmann, 2005). In the same range, still in Ouest Africa; Ghana SMEs represent $70 \%$ of all the enterprises in the country but these figures are not surprising as at least $50 \%$ of jobs in developing countries come from enterprises with at most 100 workers (Ayyagari, Demirgüç-Kunt, \& Maksimovic, 2011). This leads us to support the report of (GLOBAL, 2018) that argued business creation and innovation spur economic growth.

Startups often experience difficulties in raising capital, especially if it is meant to finance innovation. The phenomenon is generally denoted as "funding gap" (also called equity gap) (Cressy, 2002) and which is a resultant of an important information asymmetry and moral hazard problems.

Some problems undermining fund gathering for innovation are the dearth of sounds collateral which should sometimes be more valuable than the money entrepreneur want to borrow, we can also list the moral hazard problem for investors. Cosh (Cosh, Cumming, \& Hughes, 2009) demonstrated based on Empirical evidence that among startups that manage to get funding, most of them receive whether less than they would expect or not in the way they would have wanted. To address this issue, crowdfunding is one-way developed countries are using. This study aims to lay a closer look on the factors which could influence the use of the crowdfunding in Benin and then give sustainable recommendation towards its effective adoption. The crowdfunding being a system by which one can sponsor; back someone else innovation; business through an online platform without any traditional intermediaries, will revolutionize the funding procedures 
in Africa. With this method, not only domestic people will help to spur innovation and help to create companies, each African diaspora could participate in developing their respective country thus the continent as a whole. It is an area that has not been really explored as an alternative for funding in Africa, it has made its proofs in other continents.

From its birth to now, the crowdfunding sector has expanded very quickly and all most all the continents now operate crowdfunding campaigns. Allied Crowd stated This quick growth is illustrated by China who has already raised more than US\$100 billion (Crowds, 2016) what makes Asia the continent with the biggest year per year growth rate (Massolution, 2015). Countries like Philippines and India have respectively managed to raise US\$26.9 million and US\$27.8 million (Crowds, 2016). On the European and American continents, crowdfunding account respectively for US\$7 billion and US\$37 billion; while in Africa only US\$37.2 million had been mobilized by the whole continent; through platforms located in countries like Kenya, Rwanda, Tanzania, and Uganda (Crowds, 2016).

Despite these troubling figures which demonstrate how much the African continent is losing by not keeping up with the fintech evolution, there is no existing research that sought to find the factors affecting the implementation and the factors impeding the thriving of crowdfunding in sub-Saharan Africa. This study will try to fill a research gap subsisting which is the factors impeding the implementation of crowdfunding in Benin.

The significance of this research resides in the fact that it examines the causes that influence the implementation of crowdfunding in Benin and gives recommendations to a sustainable adoption of crowdfunding in Benin Republic to the good of all. This study aims to find adequate solutions to solve the equation of where to source funds to capitalize SMEs in Benin. By doing so, this study will contribute to the economic development of the country and no study has so far tackled this topic.

This work is organized around five sections, the first one was the introduction, the second, the literature reviews, after comes the study methodology followed by the data analysis and the conclusion.

\section{Equity-Based and Debt-Based Crowdfunding Overview}

\subsection{Equity-Based Crowdfunding}

Equity-based crowdfunding is a kind of crowdfunding based on investment, it consists of a set of people ploughing money into buying equity like stocks; bonds in a direct way or indirectly in the nascent enterprise or the existing company. A total amount of $£ 84$ million invested in operations was forecasted for 2014 regarding the quick bloom and spreading estimated at 201\% year-over-year rate of growth (Baeck, Collins, \& Zhang, 2014; Wardrop, Zhang, Rau, \& Gray, 2015). Among the population polled by Baeck, $96 \%$ stated that what encourages them 
to invest in a project is first, the quality of the team that built up the project along with the attractiveness of the project, what means the ways it is presented; sold. Their choices are not ushered by acquaintances. Another $75 \%$ assert what attracts them with equity-based crowdfunding is the opportunity it provides them to diversify their portfolio; the convenience of the investment mechanism and the right to monitor what is done with their money. On the same question, $61 \%$ of the backers polled estimated the financial return as their only one motive for adopting equity-based crowdfunding (Baeck et al., 2014). The particularity of this model of crowdfunding is that the amount of capital that can be raised is larger than those reached on debt-based crowdfunding model; for instance, an average of $£ 199,095$ can be drawn over 125 investors (Baeck et al., 2014). All operations in this model are made by mean of a specific platform to equity-based platform, and entrepreneurs seeking funding are from multiple domains ranging from health care to high-tech innovators.

\subsection{Debt-Based Crowdfunding}

People think of this model as a new way of lending money to people in need of it rather than a totally neo-financial product. Within this concept, network through internet is used to straight connect lenders and borrowers; this enables fundraisers to directly borrow money or lender to directly plough money debt obligations by means of a platform.

The principal objective of these platforms revolving around lending money, three main types of platforms may be identified. The nonprofit types being the first ones, backers there, aim to provide funding without hope of potential return to people that struggle to get access to traditional financing method. Examples of those types of platforms are Kiva and Zidisha; the first one collects money from backers and use existing microfinance building to lend money to people in remote area. The second one is depicted as a philanthropic association direly involved in microlending. Other examples of nonprofit platforms exist, mainly relying on donations, grants and voluntary to function. Aside the nonprofit types, we have the socially oriented lending. These ones are based on the principle of rooting for special communities or region alongside making some little profit. An illustration is MYC4 that enables SMEs to borrow money in some developing country against a small return. The third one is the so-called commercial lending platforms; Lending Club in USA, Zopa and Rain Fin respectively in United Kingdom and South Africa, plus Credit Ease in China are some instances of commercial lending platforms.

As one can tap into Debt crowdfunding for a broad range of purpose; three fundamental sub-models are distinguished to meet everybody's needs. As per (Savarese, 2015), the sub-model following which individual lenders are allowed to lend money to other individual raising money or other entrepreneurs is called P2P Lending, and the decision of trusting a fundraiser to contribute to a part or to the totality of the amount needed. 


\section{Methodology}

\subsection{Scientific Approach}

The array of scientific method the science offers us to make the solution we gave using a specific method on a specific problem, only one solution among many others (Fuglsang \& Olsen, 2004). Because in this paper we are more into trying to figure out causalities or correlation between variables in order to find rather than drawing general conclusions from empirical observations, we will then make use of a positivism philosophy coupled with a deductive reasoning. A qualitative method will be slightly used as a complement. See Figure 1 below.

\subsection{Research Design}

On basis of thorough review of existing literature and heavy brainwork, an initial framework was developed (Figure 2). The initial framework comprehended six principal study segments that could affect the implementation and the use of crowdfunding in Benin. They were; environmental factors; laws and regulations; Financial Capabilities; data privacy; organizational factors and Technological factors. These were the six windows through which I initially chose to screw the reasons blocking the implementation and the use of crowdfunding in Benin.

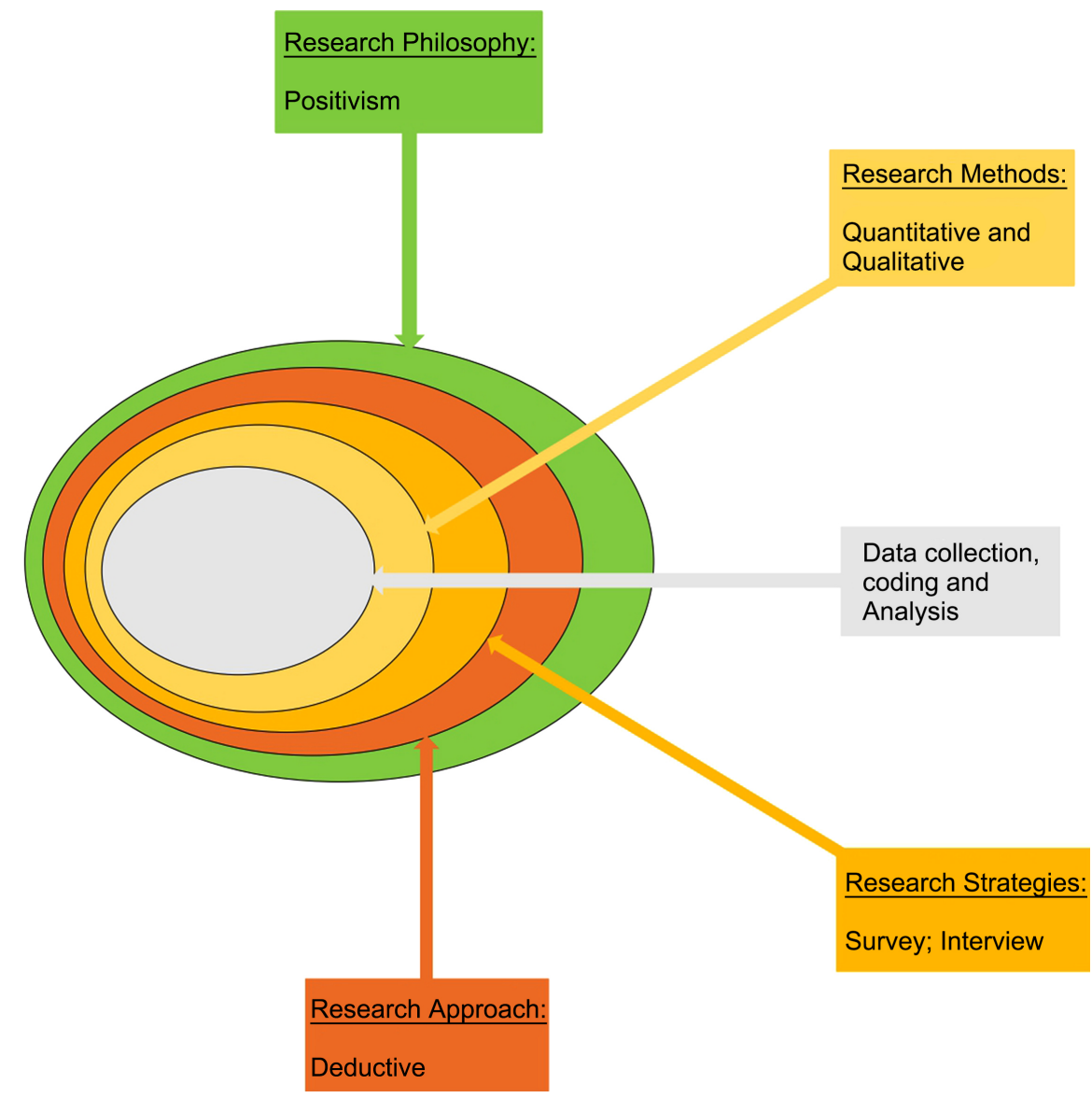

Figure 1. Scientific approach. 
Laws and Regulations

- Regulatory framework

- Licensing,

- Governance

- Financial consumers'

protection

- Cyber security

instructions

Financial Capabilities

- Financial wellbeing

- Financial behavior

- Financial education

Technological factors

- Relative advantages

- Compatibility

- Complexity

- Accessibility

- Availability

- Sustainability

- Cost of implementation

- Technical skills

Figure 2. Initial framework.
Data Privacy

- Personal information disclosure

- Proprietorship of projects exposed

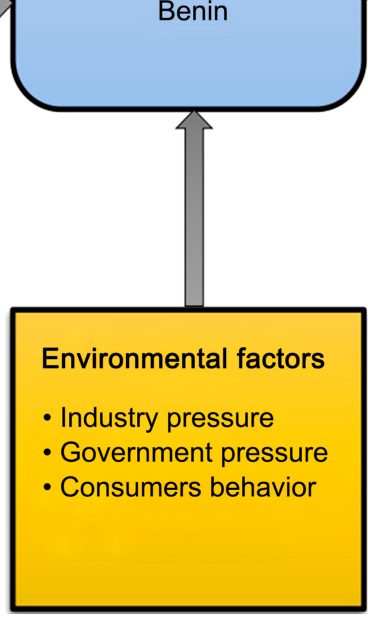

Environmental factors

Factors affecting the Implementation of Crowdfunding in Benin

Organizational factors

- Information products characteristics

- Security and trust

- Payment system

- Platform Administration

- Reliability of Credit

Scoring tools

- Creditworthiness measurement

Once this done, the initial framework was reviewed by a group of seven experts composed of financial academics in Benin; business men currently in Benin; members of the management board of the Chamber of Commerce and Industry of Benin (CCIB) in addition to my supervisor. This was done in order to know if in light of the current business environment prevailing in the country, the factors outlined by the initial framework I drew were meaningful to really illustrate what could be preventing the installation and the use of the alternative finance source that is crowdfunding. Besides this, it was a great way to get insights from those resource persons on the key point to be tackled when designing the questionnaire to be addressed the surveyed (Figure 3 ).

The team of expert was composed of 2 Financial management professors; 1 Risk management professor; 2 members of the management board of the Chamber of Commerce and Industry of Benin (CCIB), 1 agent of the ministry of Economics and Finances and at last my supervisor who is an Accounting and Finance teacher. 


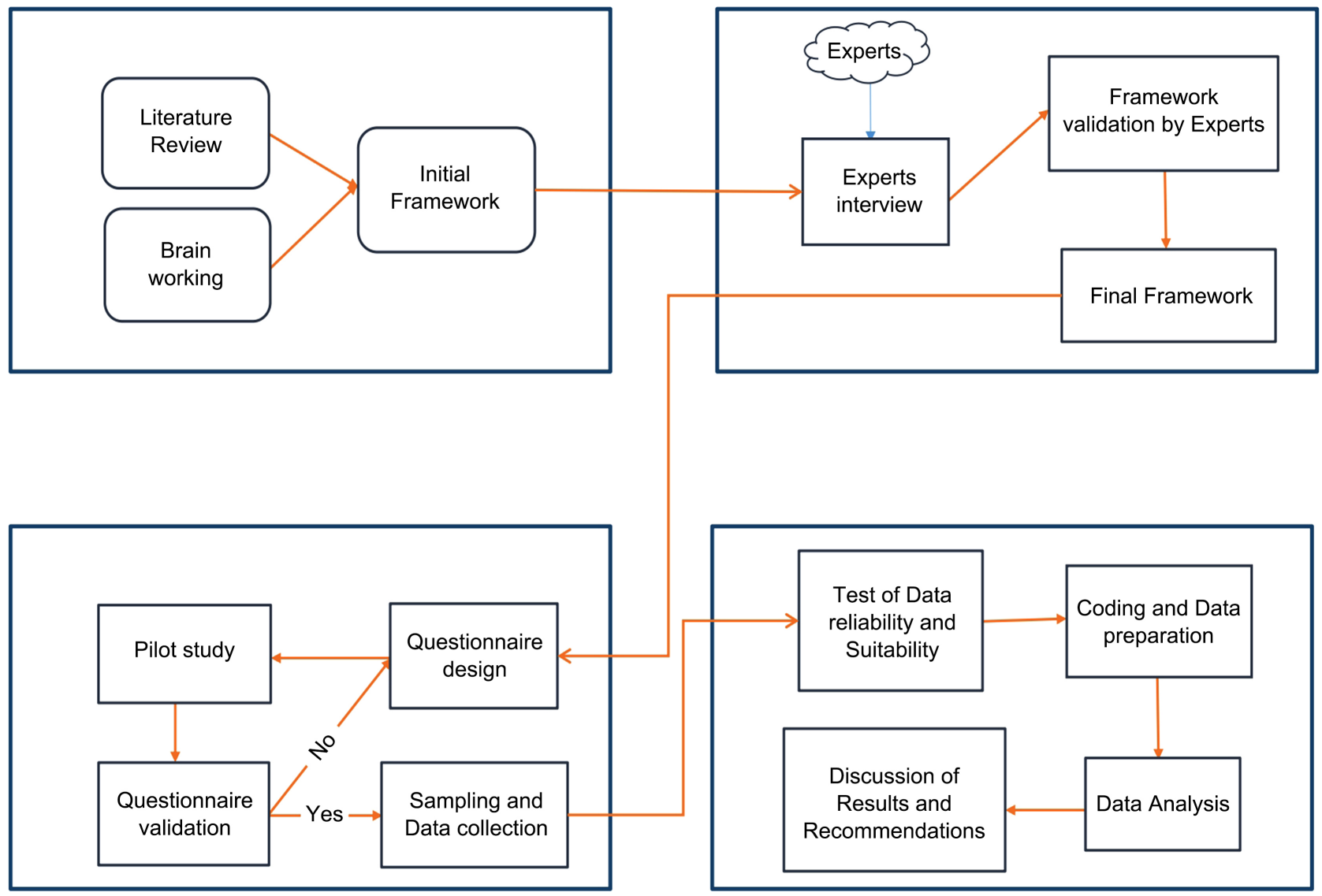

Figure 3. Research model.

For the interview, two main parts could be distinguished on the questionnaire. The first one was about what they think about crowdfunding in general; which types they think have more chances to thrive in Benin business environment. The second part focuses on the main components of the initial framework. To know what they think about it and to help ranking it in order of relevance according to their knowledge of the economic and financial situation of the country.

\subsection{Screening Process of Influencing Factors}

The interviews were very rich in information and were very useful in the conduct of the study. All the experts agreed on the fact that debt-based crowdfunding and Equity crowdfunding were most likely to succeed than the reward-based and the donation-based one. Their arguments were that:

- Debt-based and equity-based crowdfunding could be used to raised significant amount to capitalize a business because of the fact that people would be expecting a financial return on their investment; whereas for the donationbased and reward-based there is no incentive for people to give out their money to support people or projects. How many people are that enough rich to give out their money to sponsor a project or an innovation in Benin without any consequent return? The answer to that question is, very little. We are 
a developing country that has just started building its economy.

- Debt-based and equity-based crowdfunding will allow diaspora people seeking what to invest in, to have investments opportunities in their home country but this will depend on the degree of trust built between them and the organization running the crowdfunding platform. This being they recommended us to investigate on trust when surveying possible funders.

For the first segment of the interviews; they were unanimous on the fact that the study is very relevant and would lend a great hand for SMEs growth and to employment creation. They were all negative about the chances of outreaching of the reward-based crowdfunding and the Donation-Based Crowdfunding. For them, chances of taking off of those two types of crowdfunding are very thin.

About the second part of the interview, a statistical analysis of the outcomes of the interview helped me to rank the factors listed in the initial framework by order of priority and to eliminate the very less important. In fact, we gave the opportunity to our interviewee to grade each factor on scale of 0 to 6 . We later eliminated factors that did not meet the score of 14 over 42 . After ranking each factor, experts gave their critical view on each factor that was underlined by the initial framework. Hereunder are some main points to be kept.

- They explained saying that the fact that Environmental factors encompassed Industry and Governmental pressure in addition of consumer behavior makes it less valuable because at first, there will be no industry pressure following the fact there is no existing FinTech industry, the consumer behavior is already measured by the "Openness to Technology" and the "Security and Trust" respectively presents in the Technological factors and in the Organizational factors. They went further saying the "Government pressure" in the Environmental factors are already depicted under the "Laws and regulations", because the government pressure would be measured by the "Regulatory framework" to follow and the "Licensing".

- On the Data privacy; they suggested to simply remove that factor because taking into consideration how much Beninese expose their private life on social medias like Facebook, Instagram, WhatsApp, YouTube and so on, this could not be a barrier to the use of crowdfunding.

- About the financial capabilities, they also found it not to be a substantial impediment because the young generation is well educated and considering the population of funders we are facing, they are willing to pull out money for investment, they are the same sending remittances to their parents and friends to start business and most of them are seeking investment opportunities.

In sum, the three factors above cited didn't meet the standard set to be taken into account among factors impeding the establishment and the use of crowdfunding in Benin. Among the three other factors, "Laws and Regulations" came first followed by "Organizational Factors" and at last "Technological factors". See Figure 4 for the final framework. 


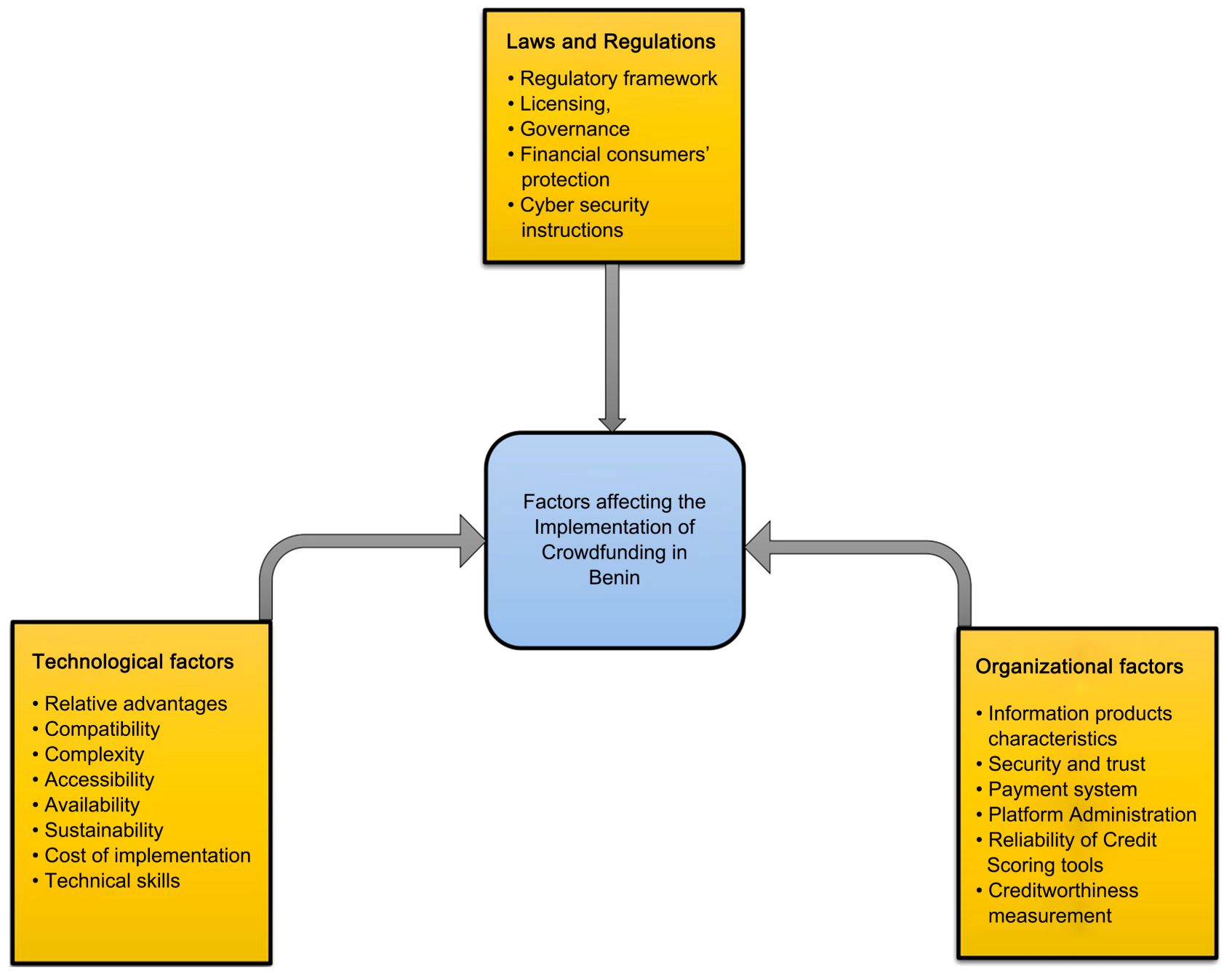

Figure 4. Final framework.

\subsection{Research Hypotheses}

The screening process of influencing factors was really helpful to draw the final framework and to draw the following hypothesis:

H1: From the funders' view, there is a strong relationship between existence of sound "Laws and regulations" and the implementation and adoption of crowdfunding in Benin.

$\mathrm{H} 2$ : There is a significant link between easing the "Technological factors" and the implementation and adoption of Crowdfunding in Benin according to the Funders.

H3: There is a valuable relationship between the "Organizational factors" and the implementation and the adoption of Crowdfunding in Benin from the funder's view.

\subsection{Sample Design}

The sample of a study can have a profound impact on the outcome of a study. 
The sample is simply the participants in a study. Simple random sampling is used in this case to allow each person to have same chance as another of being selected. The sample frame was obtained from exhaustive list of all Benin diaspora member residing in China and Canada and registered at the respective Embassies of Benin in China and Canada. The study targeted Benin diaspora member in China and Canada that have spent at least two years in their host country with a stable financial condition and also who are used to sending remittance to Benin. Following the list obtained from diverse embassies, 400 is the number of Beninese in those two countries that have spent two years and have a stable financial capability.

To collect the primary source data, a questionnaire was designed with askform.cn and the link was sent to everybody via one of the following means: WeChat, WhatsApp and mail.

In order to make the sample representative enough to inspire confidence in the result of the research, Solvin's formula is involved to determine the number of samples needed to have a valid study.

$$
\mathrm{n}=\mathrm{N} /(1+(\mathrm{Ne} 2))
$$

$\mathrm{n}=$ Number of samples; $\mathrm{N}=$ Total population; $\mathrm{e}=$ error tolerance level.

In this case: Our population is $\mathrm{N}=400$; $\mathrm{e}=0.05$

$$
\mathrm{n}=400 /(1+(400 \times 0.052))=200 .
$$

Therefore, we need at least 200 participants to assert the sample is representative enough to inspire confidence.

In all, 328 responses to the survey were obtained, which means 128 more than the minimum required to have a meaningful sample.

\subsection{Data Analysis Method}

In this study, data will be analyzed using statistical software (SPSS) version 26. First descriptive statistic method is used to gauge the level of accordance of the population surveyed with the variables that were put forth to analyze the factors influencing on the implementation of the crowdfunding system in Benin. Afterward, the reliability and the consistency of the data collected were tested with the Cronbach's Alpha coefficient.

Furthermore, follows the correlation analysis to analyze and measure the degree of significance in relationship between the implementation of Crowdfunding; Rules and regulations, the organizational factors and the technological factors by a statistical mean. The correlation analysis encompasses a simple linear regression analysis method to measure the relationship between each independent variable (Rules and regulations; Organizational factors; Technological factors) and the dependent variable (implementation and use of crowdfunding); it comprehends also a multiple regression analysis which enables of the relationship existing between the dependent variable and the independent variables. 


\section{Discussion of Major Findings}

This section aims to test hypothesis's study. All data collected through the questionnaire will be used to get the results. To be able to do that analysis, the program IBM SPSS Statistic version 26 is used.

\subsection{Frequency Distribution}

$$
\begin{aligned}
& 5 \rightarrow \text { Very High } \quad 3 \rightarrow \text { Average } \quad 2 \rightarrow \text { Low } \\
& 4 \rightarrow \text { High } \quad 1 \rightarrow \text { Very Low }
\end{aligned}
$$

Table 1 shows the summary of the frequency distribution; the mean; the standard deviation and the ranking of the subfactors composing each factor according to the participants. The ranking was done to show what factors people think are primordial if a sound and successful crowdfunding system is to be implemented in Benin. A score of 5 denotes a very high agreement with the importance of the factor indicated; a score of 4 suggests a high level of importance of the factor in question; a score of 3 is to signify an average agreement on the significance of the contribution of the factor suggested in the implementation of a successful crowdfunding industry in Benin. Scores of 2 and 1 respectively indicate a low and very low impact of those variables on succeeding to put in place a good and prosperous system of crowdfunding in Benin.

A quick analysis of the frequency distribution summary and it is noticeable all the 328 participants taken together, ranked Laws and Regulations factor as first to be taken in consideration in order to install a sound and sustainable crowdfunding with a mean of 4.134. According to them, Laws and Regulations factor has a high impact on the outcome of the process of successfully implementing the crowdfunding. The Organizational Factor comes second in the order of privilege drawn by the 328 participants with a mean of 4.09 . This denotes they also assign a high value to the organizational factors around the crowdfunding to be installed. Finally comes the Technological Factor with a mean score of 3.43 which clearly signifies a high average importance of the factor in determining whether or not the system to be implemented will interest people and gain enough their confidence in a way they definitively adopt it as a substitute of the traditional founding means.

Even though each of the general factors was classified following the mean score of their components, it is to be noted that the variables summated to compose each general factor do not have the same importance according to the participants. Taking into consideration their rating, some variables within the Technological factor, are much more important than some variables within the Laws and regulations factor, so do certain of the variables that the organizational factor encompasses compared to the variables summated under the umbrella of the Technological factor and the Laws and regulations factor. This leads us to the differentiation of two sets of variables according to the level of importance given to them by the surveyed. A fact that is undeniable is that all the variables introduced to explain the factors that could represent any kind of impediment to the 
implantation of a crowdfunding system in Benin were evaluated as factors of high importance to be considered while drawing implementation plans of the crowdfunding. Be that as it may, the two categories that jump out are a category with mean scores of at least 4 that denotes that people require high attention to be lent to those variables and another category with mean scores of above averages and very close to a score of 4 . This last category encompasses variables that still need consequent attention but come after the first set of variables in the ranking by order of importance according to the surveyed.

Hereafter (Table 2) comes some further explanation about each variable and the meaning related to each score that was attributed to them.

Table 1. Frequency distribution summary.

\begin{tabular}{|c|c|c|c|c|c|c|}
\hline Variables & Items & Mean & S. D. & Rank & Level & Order \\
\hline \multirow{5}{*}{$\begin{array}{l}\text { Laws and } \\
\text { Regulations }\end{array}$} & Regulatory Framework & 4 & 0.904 & 4 th & High & 10th \\
\hline & Licensing & 4.23 & 0.883 & $3 \mathrm{rd}$ & High & 6th \\
\hline & Governance & 3.67 & 1.142 & 5 th & Upper Average & 18 th \\
\hline & Financial Consumer Protection & 4.4 & 0.747 & 1 st & High & 2nd \\
\hline & Cyber security & 4.37 & 0.965 & 2nd & High & 4 th \\
\hline \multirow{8}{*}{$\begin{array}{l}\text { Technological } \\
\text { Factors }\end{array}$} & Relative advantages & 3.89 & 0.1 .003 & 4 th & Upper Average & 12 th \\
\hline & Complexity & 4.09 & 0.921 & 1 st & High & 7 th \\
\hline & Accessibility & 4.09 & 0.921 & 1 st & High & 7 th \\
\hline & Availability & 4.09 & 0.921 & 1 st & High & 7 th \\
\hline & Sustainability & 3.81 & 1.002 & 5 th & Upper Average & 14 th \\
\hline & Cost of Implementation & 3.73 & 1.124 & 7 th & Upper Average & 16 th \\
\hline & Technical Skills & 3.73 & 1.124 & 7 th & Upper Average & 16 th \\
\hline & Openness to Technology & 3.81 & 1.002 & 5 th & Upper Average & 14 th \\
\hline \multirow{6}{*}{$\begin{array}{l}\text { Organizational } \\
\text { Factors }\end{array}$} & Information, products characteristics & 3.87 & 0.959 & 5 th & Upper Average & 13 th \\
\hline & Security Trust & 4.4 & 0.747 & 2nd & High & 2nd \\
\hline & Payment System & 4.41 & 0.653 & 1 st & High & 1 st \\
\hline & Platform Administration & 3.67 & 1.142 & 6th & Upper Average & 18 th \\
\hline & Reliability of Credit scoring tools & 3.92 & 1.113 & 4 th & Upper Average & 11 th \\
\hline & Creditworthiness measurement & 4.28 & 0.833 & $3 \mathrm{rd}$ & High & 5 th \\
\hline \multirow{4}{*}{$\begin{array}{l}\text { Implementation of } \\
\text { Crowdfunding }\end{array}$} & Reduction of Credit Cost & 3.73 & 1.174 & $3 \mathrm{rd}$ & Upper Average & \\
\hline & Increase availability of funding & 4.28 & 0.833 & 1 st & High & \\
\hline & Promote entrepreneurship & 3.73 & 1.174 & $3 \mathrm{rd}$ & Upper Average & \\
\hline & Promote Investment & 4.28 & 0.833 & $1 \mathrm{st}$ & High & \\
\hline
\end{tabular}


Table 2. Variables with a score above 4 on the scale of 5 .

\begin{tabular}{cccc}
\hline Items & Mean & Level & Order \\
\hline Payment System & 4.41 & High & 1 st \\
Financial Consumer Protection & 4.4 & High & 2nd \\
Security Trust & 4.4 & High & 2 nd \\
Cyber security & 4.37 & High & 4 th \\
Creditworthiness measurement & 4.28 & High & 5 th \\
Licensing & 4.23 & High & 6 th \\
Complexity & 4.09 & High & 7 th \\
Accessibility & 4.09 & High & 7 th \\
Availability & 4.09 & High & 7 th \\
Regulatory Framework & 4 & High & 10 th \\
\hline
\end{tabular}

What came first in the priority order is the variable "Payment System". People surveyed think inadequate payment system could be a great impediment to establishing good crowdfunding in the way that most funders even if they are Beninese, they are outside the country and this makes things a bit more complicated. Remittances costs for sending money back Africa form outside the continent or even within the continent are huge. A mean to lessen bank transfer cost should be found or a mean to pay or fund a venture without bearing additional cost will be very helpful and will even motivate people to participate in campaigns.

Items that followed and came along side at the second place are "Financial Consumer protection", and "Security Trust". The fact that Financial consumer comes second among the twenty-three items means that people require a strong financial consumer protection in order to help them making righteous decisions on the optimum way of choosing venture in which to invest and that correspond them the most by disclosing and making available necessary information.

For the "Cyber security" the fact that it was brought out as one of the variable the most concerned about implies that if a well-structured security protocol is not elaborated to protect the crowdfunding platforms and systems from unauthorized access or from harmful attack that could leave the entire system upside down and even cause the financial market created around the crowdfunding system to crash, people would not be prompt to adopt the crowdfunding system.

The "Creditworthiness Measurement" was ranked 5th, this denotes funders are very concerned about knowing whether people they are giving money to are solvable; especially funders with interest in Debt-based Crowdfunding. The fintech being introduced will be much more accepted and result in a successful implementation if they feel secured about the "Creditworthiness Measurement" factor.

Another variable that received a high score on the importance scale and which came 6th is the "Licensing" factor, with a mean score of 4.23 over 5 , the ranking 
of this variable suggests people with saving surplus and willing to invest would be more attracted and more incline to use crowdfunding if there is a clear and a formal attestation of recognition delivered by the regulators that they authorize the system to be put in work. This is because in the pass times people have been deceived by people that collected their savings and disappeared leaving people with nothing and worst is that the government said they were not aware of what was going on. Queuing at the 7th position, we have "Complexity", "Accessibility" and "Availability" variables, their scores are above 4 which means they are of high importance according to people. This suggests that people value the level to which the new technology brought to them would be relatively easy to understand and to use, along with the readiness with which they could have access to the platforms on any surface and everywhere. These are some factors that can lure people to the use or repel them. At last, to seal the loop of variables with high impact on the outcome of the crowdfunding implementation came the variable "Regulatory Framework". Surveyed, by ranking this variable at the tenth position are hereby asserting that proper regulations are needed to monitor all the components of the crowdfunding ecosystem to ensure their ways of functioning match regular standards and do not clash with existing regulation.

Table 3 shows that Reliability of Credit scoring tools came with a score high above average which suggests people do care about the extent to which tools used to measure people solvability are reliable. This will help them in getting confident about giving their money to people who are not their family and also help them making righteous investment decisions.

Relative advantage this could be a determinant factor in setting up the crowdfunding system in Benin because, the relative advantage being the Point at which the advent of an innovation is seen to be more important and more beneficial than something that have existed prior it, a great work should be done on this, to sensitize people on why this mean of funding is better and is more promising for the future of our development than the traditional funding means.

Table 3. Variables with a score above 3.60 on the scale of 5 .

\begin{tabular}{cccc}
\hline $\begin{array}{c}\text { Reliability of Credit scoring tools } \\
\text { Relative advantages }\end{array}$ & 3.92 & Upper Average & 11th \\
Information, products characteristics & 3.89 & Upper Average & 12th \\
Openness to Technology & 3.87 & Upper Average & 13 th \\
Sustainability & 3.81 & Upper Average & 14th \\
Cost of Implementation & 3.81 & Upper Average & 14th \\
Technical Skills & 3.73 & Upper Average & 16th \\
Platform Administration & 3.73 & Upper Average & 16th \\
Governance & 3.67 & Upper Average & 18th \\
\hline
\end{tabular}


Sustainability Openness to Technology for most of funders, making transactions, fund raising, and access to new financial market easy and durable are some of thing that would have a great impact on the attempt to implement such system. These variables coming at the 14 th place could also be explained by the fact they think people are open minded and that the openness to technology would not be a real impediment factor to a successful implementation.

Cost of Implementation and Technical Skills are also considered as of nonnegligible impact because people would be more prone to adopt and make active use of the new fintech being introduce to them if only they notice that people in charge of setting the system up are people well equipped with the adequate technological knowledge to build a sustainable and reliable system. They also think that a huge cost of implementation would make platform fees high and there would not be much difference in the credit cost with the traditional existing funding institution. This could cause people not to value the innovation brought to them and may lead to a failure in the implementation of the crowdfunding system

Governance and Platform Administration variables came last but with an upper average score to denote they are not paramount variables in the implementation of the crowdfunding system in Benin but they are not also to be neglected. Surveyed believe, as long as there is good regulatory framework, good technical skills, strict and reliable creditworthiness measurement, credit scoring tools, good Governance and Platform administration would follow. But these variables are enough important to determine whether a sustainable and great confidence would be built in using crowdfunding.

\subsection{Reliability and Validity}

The reliability and validity of the Likert Scale questionnaire were proved by means of a Cronbach's alpha test and a Pearson correlation coefficient computation in SPSS. It was found that all the questions were statistically significant with Cronbach's alfa of all variable dwelling between $65 \%$ and 86 . Which mean that $65 \%$ to $86 \%$ of variance in the score are reliable variables.

\subsection{Correlation}

The correlation table shows significant positive correlation between each independent variable and the dependent variable. The Pearson's analysis presented the correlation between the different independent variables on one hand. The results table showed all the independent variables are positively correlated at the level of $1 \%$ and the correlation coefficients ranged from 0.36 to 0.62 . On the other hand, the Pearson's analysis also depicted correlation between each independent variable and the dependent variable. The coefficients range from 0.34 to 0.63 indicating that a good technological and organizational environment plus well-drafted laws and regulations will positively impact the adoption of the crowdfunding system. The highest correlation coefficient of 0.63 in between 
crowdfunding implementation and Organizational factors, which means a good organizational system is primordial for the acceptance and the adoption of crowdfunding by Beninese.

\subsection{Simple Regression}

From the simple regression analysis operated it came out that Crowdfunding implementation regression on technological factor has given a value of $P<$ 0.001 . Crowdfunding Implementation also has good regression with both Organizational factor and Laws and regulation factor with given $P$ value of $P<0.001$. This being, all the three hypotheses of the study are validated and it can be asserted that statistically significant relationship does exist between each predictor or independent variable in the model and the dependent variable. See Tables 4-9.

- Laws and Regulations.

- Technological factor.

- Organizational factors.

\subsection{Multiple Regression}

In order to determine how well different variables; technological; organizational and Law and regulations factors work together to help to predict a successful crowdfunding implementation, a multiple regression analysis was performed. The scatterplot got after creating an unstandardized value with the three independent variables and regressing it with the dependent variable showed that the relation existing between the independents factors and the dependent factor is fair positive linear relationship. On the other hand, Law and regulation factor has been found statistically non-significant in the model. It is to be noted that the Law and regulation factor being found as statistically non-significant at the level of $P$ value $P=0.001$ does not mean that the variable is useless to the model. This rather means there is a possibility that Law and regulations factor is not really key determinant for a successful Crowdfunding Implementation in Benin. Correlations between crowdfunding implementation and predictors variables were found to be statistically significant. They are denoted as follow; the relationship between the crowdfunding implementation and the technological factor; $\mathrm{r}(327)=0.344, p<0.001$; crowdfunding implementation and the organizational factor $\mathrm{r}(327)=0.629, p<0.001$; Crowdfunding implementation and Law and regulations factor, $\mathrm{r}(327)=0.364, p<0.001$. The regression equation for predicting Crowdfunding implementation from predictors variable was

$$
\hat{Y}=0.146-0.83(x 1)+0.95(x 2)+0.937(x 3)
$$

with $p<0.001, \mathrm{r} 2$ for this equation is $\mathrm{r} 2=0.403$, which represents $40 \%$ variance in crowdfunding implementation and says that the variables taken into account in this study cover $40 \%$ of the prediction of a good crowdfunding implementation. This is moderate good relationship. See Table 10 and Table 11. 
Table 4. ANOVA ${ }^{\mathrm{a}}$ laws and regulations.

\begin{tabular}{ccccccc}
\hline \multicolumn{2}{c}{ Model } & Sum of Squares & df & Mean Square & F & Sig. \\
\hline & Regression & 25.177 & 1 & 25.177 & 49.650 & $0.000^{\mathrm{b}}$ \\
1 & Residual & 165.311 & 326 & 0.507 & & \\
& Total & 190.488 & 327 & & & \\
\hline
\end{tabular}

a. Dependent variable: crowdfunding implementation; b. Predictors: (Constant), laws and regulation.

Table 5. Model summary laws and regulation.

\begin{tabular}{ccccc}
\hline Model & $\mathrm{R}$ & R Square & Adjusted R Square & Std. Error of the Estimate \\
\hline 1 & $0.364^{\mathrm{a}}$ & 0.132 & 0.130 & 0.71210 \\
\hline
\end{tabular}

a. Predictors: (Constant), laws and regulation.

Table 6. ANOVA ${ }^{\text {a }}$ technological factor.

\begin{tabular}{ccccccc}
\hline \multicolumn{2}{c}{ Model } & Sum of Squares & df & Mean Square & F & Sig. \\
\hline & Regression & 22.585 & 1 & 22.585 & 43.850 & $0.000^{\mathrm{b}}$ \\
1 & Residual & 167.903 & 326 & 0.515 & \\
Total & 190.488 & 327 & & \\
& & & &
\end{tabular}

a. Dependent variable: crowdfunding implementation; b. Predictors: (Constant), technological factor.

Table 7. Model summary technological factors.

\begin{tabular}{ccccc}
\hline Model & $\mathrm{R}$ & R Square & Adjusted R Square & Std. Error of the Estimate \\
\hline 1 & $0.344^{\mathrm{a}}$ & 0.119 & 0.116 & 0.71766 \\
\hline
\end{tabular}

a. Predictors: (Constant), technological factor.

Table 8. ANOVA a organizational factors.

\begin{tabular}{|c|c|c|c|c|c|c|}
\hline & Model & Sum of Squares & df & Mean Square & $\mathrm{F}$ & Sig. \\
\hline \multirow{3}{*}{1} & Regression & 75.400 & 1 & 75.400 & 213.580 & $0.000^{\mathrm{b}}$ \\
\hline & Residual & 115.088 & 326 & 0.353 & & \\
\hline & Total & 190.488 & 327 & & & \\
\hline
\end{tabular}

a. Dependent variable: crowdfunding implementation; b. Predictors: (Constant), organizational factors.

Table 9. Model summary organizational factors.

\begin{tabular}{ccccc}
\hline Model & $\mathrm{R}$ & R Square & Adjusted R Square & Std. Error of the Estimate \\
\hline 1 & $0.629^{\mathrm{a}}$ & 0.396 & 0.394 & 0.59416 \\
\hline
\end{tabular}

a. Predictors: (Constant), organizational factors. 
Table 10. Model summary.

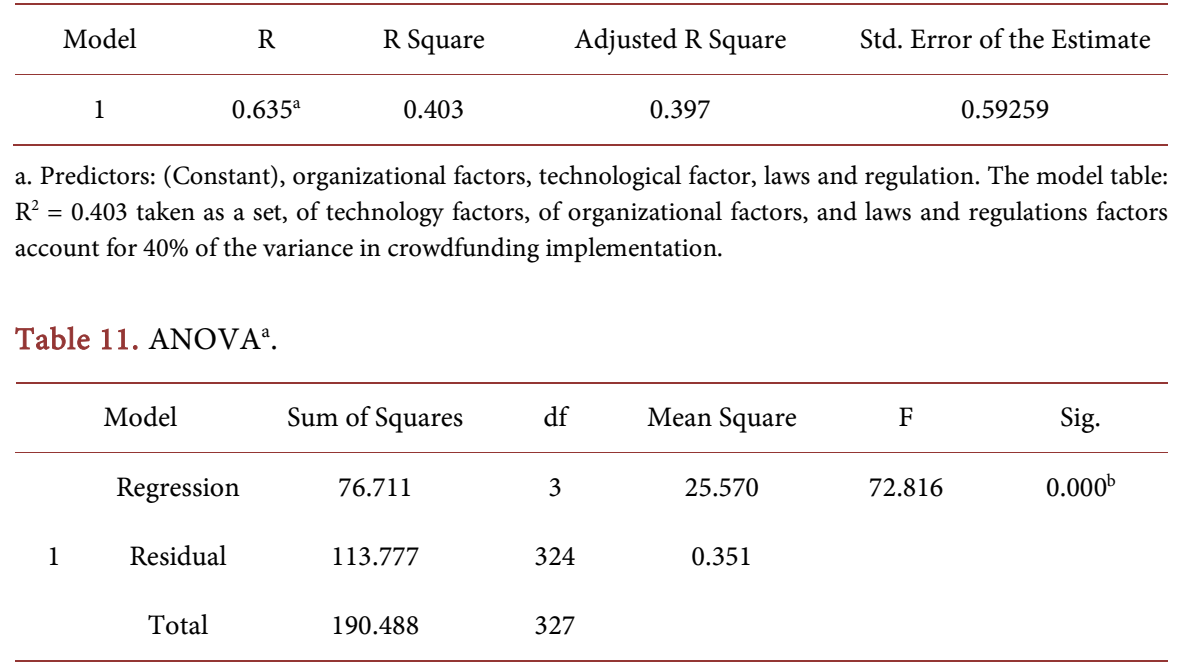

a. Dependent variable: crowdfunding implementation; b. Predictors: (Constant), organizational factors, technological factor, laws and regulation.

\section{Conclusion and Recommendations}

\subsection{Conclusion}

In order to make a substantial contribution to the economic development of Benin in particular and Africa in general, this study was thoroughly conducted with the paramount aim of coming out with a suitable solution to the funding equation that has always been undermining the thriving of many sectors of our economy. This would be a great blow to the takeoff of the industrialization of Benin and for many other countries in Africa. To achieve that aim some objectives were defined as followed; the first was to determine causes impeding the implementation of crowdfunding in Benin, second to find out the relation existing between the technological context and the effective implementation of crowdfunding concept in Benin. In third position, it was planned to determine the relationship linking the organizational environment with the implementation of crowdfunding in Benin; the fourth point was to point out the link between business environmental context prevailing in Benin and the implementation of a successful crowdfunding system. Finally, to give recommendation to a successful adoption of crowdfunding as an alternative funding source by SMEs in Benin.

The frequency analysis revealed that people think all the variables suggested are relevant to a sustainable and successful crowdfunding implementation in Benin as on a Likert scale of 5 points, $44 \%$ of the variables got a score above 4 and the $56 \%$ left have a score above 3.60 . Despite the undoubtable importance of all the variables, we came to notice that for people to accept and adopt crowdfunding as the study would like, some variables like "Payment System"; "Financial Consumer Protection"; "Security Trust”; "Cyber Security"; "Creditworthiness"; "Licensing"; “Complexity”; “Accessibility”; “Availability”; “Availability”; 
"Regulatory Framework" are of paramount importance, then follow the other variables as "Reliability of credit scoring"; "Relative Advantages"; "Information, product characteristics"; "Openness to Technology"; "Sustainability"; "Cost of Implementation"; "Technical Skills"; "Platform administration" and "Governance". On the other hand, the Cronbach Alpha Test denoted a strong internal consistency of the measurement instrument that was used in the survey, in other words, the Cronbach Alpha test coefficients lying between 65\% to $86 \%$ revealed a strong reliability of the questionnaire used to collect data in the study. The correlation and the simple regression analyses helped to demonstrate there is correlation existing among the three factors used to explain what could be a barrier for implementing crowdfunding. They also helped to validate all the three hypothesizes.

This study by giving such results aligns with some authors like (Mollick, 2014; Rau, 2017; Cordova, Dolci, \& Gianfrate, 2015) who did argue regulatory framework is of great importance for a crowdfunding system to work; the findings are also supported by some scholars findings like (Rau, 2017; Ibrahim, 2012; Gerber, Hui, \& Kuo, 2012) who asserted Environmental factors are very important for the implementation of a sustainable crowdfunding system in any country. The conclusions of thy study also go in the same direction as the outcome of some scholars' studies (Mollick, 2014; Samarah \& Alkhatib, 2019), that did emphasize Technological factors are of paramount importance to have a great Crowdfunding system.

To determine how well different factors, work together to help to predict a successful crowdfunding implementation, the multiple regression analysis performed showed that correlations between crowdfunding implementation and predictors variables are statistically significant but only predict $40 \%$ of a good crowdfunding implementation.

\subsection{Recommendations}

Here are some recommendations made after identifying factors that are most likely to influence the crowdfunding implementation and adoption in Benin Republic. To access the problem of Security Trust; Platform Administration; Reliability of Creditworthiness measurement; Technical Skills; Accessibility; Availability; Complexity; the study recommends to seek the help of an international expert in the field of crowdfunding to organize roundtable discussions; workshops sections; due to the lack of practical knowledge in general and in regulating aspect in particular. This will help in training qualified people to well manage the crowdfunding system to set in place; it will also help to master all the models and sub-models that Equity- and Debt-based crowdfunding encompass; how to operate them; how to measure credit worthiness; it will also help the introduction of new credit scoring tools. Requiring expertise from a sound and successful crowdfunding platform board will help to design a very light and secured system which could be accessible from everywhere and would guarantee 
security to the users.

To compensate the problem of Licensing; Implementation Cost and Governance, the study suggests to create only one platform in Benin that would be under the tutelar of an affiliated branch of the ministry of Economy and Finances. The study also recommends to place this the platform under the jurisdiction of the Benin Court of Repression for Economic and Terrorism Offenses, plus the Economic and Financial Brigade of Benin.

To solve the problem of Relative Advantage; Acceptation an Openness to Technology Sustainability it will be good to organize official meeting lead by scholars and members of the ministry of finances and Economy; to raise awareness of people about what is going to come in place and the extent to which it is profitable for the Benin young and future generation. To do so, official meetings should be held in universities, to foster the desire of entrepreneurship among students; to show them there will be support for them when their Ideas are interesting and innovative. Those meetings will have the goal to show people how crowdfunding work; how their ideas would be evaluated; the procedures to conduct a successful crowdfunding campaign; the rules and regulation they have to abide by; what are the policies set to severely punish anyone that would try any kind of fraud. One major thing is also that all the embassies of Benin abroad should be obliged to hold official meetings to sensitize various Beninese diaspora members of what is being implemented; and the various advantages it presents for them and the country development. This is a paramount point because the participation of diaspora people is a key stone to the thriving of this system. They are the most likely to have excess of savings they would like to invest instead of keeping their money at home or saving them in banks with low interests. People from the diaspora are also the most prone to transfer competencies to their home countries with innovative ideas drawn on what they have seen wherever they are and how they could adapt them to Benin realities to better existing habits. The government should also sensitize different existing cooperative.

To make transactions easy, due to the country's reality, the study recommends Benin republic government to pay the salary of the platform manager and those of people in charge of the platform maintenance. This will drastically lessen the fees charged when funds are raised for a project through the platform. The government should also set a congregation of lawyer to take care of the necessary parameters of diverse contracts to be signed involving different parties in a project, to avoid future conflicts.

To settle the issue of payment system, the government should set up policies to make formal and easy money transfer back home. Transferring money from abroad to Benin is most of time tainted of tedious work and burdensome transfer cost that could easily discourage people at time. A simple solution to that would be the government to back existing small size Beninese structure operating in the domain of money transfer. Startups like Edgard Transfer or Dominik 
Transfer have been helping Beninese and Africans in China to send remittances back home at lower cost; it will ease the money transfer in what concern crowdfunding system in case someone in china wants to invest in a project in Benin. After been backed up by the government, it will push even skeptical person to use those startups services. The government should also encourage those kinds of initiative to be set in other diasporas.

After all these, it is also important to display figures on the crowdfunding portal about the success rate of crowdfunding campaigns and about how the enterprises it contributed to create are evolving. This will trigger the interest in other people to use the system.

Taking into account the cultural aspect of Benin realities, I would suggest to make use of the Benin cultural instrument called FA, to evaluate the sustainability of each project, to make sure people taking part in a project are the most suitable for that project.

\section{Conflicts of Interest}

The author declares no conflicts of interest regarding the publication of this paper.

\section{References}

Ayyagari, M., Demirgüç-Kunt, A., \& Maksimovic, V. (2011). Firm Innovation in Emerging Markets: The Role of Finance, Governance, and Competition. Journal of Financial and Quantitative Analysis, 46, 1545-1580. https://doi.org/10.1017/S0022109011000378

Baeck, P., Collins, L., \& Zhang, B. (2014). Understanding Alternative Finance-The UK Alternative Finance Industry Report 2014. Cambridge: Cambridge Centre for Alternative Finance.

Cordova, A., Dolci, J., \& Gianfrate, G. (2015). The Determinants of Crowdfunding Success: Evidence from Technology Projects. Procedia-Social and Behavioral Sciences, 181, 115-124. https://doi.org/10.1016/j.sbspro.2015.04.872

Cosh, A., Cumming, D., \& Hughes, A. (2009). Outside Enterpreneurial Capital. Economic Journal, 119, 1494-1533. https://doi.org/10.1111/j.1468-0297.2009.02270.x

Cressy, R. (2002). Introduction: Funding Gaps: A Symposium. The Economic Journal, 112, F1-F16. https://doi.org/10.1111/1468-0297.00680

Crowds, A. (2016). Developing World Crowdfunding: Annual Report 2016. London: Allied Crowdsorld Crowdfunding.

Fjose, S., Grünfeld, L. A., \& Green, C. (2010). SMEs and Growth in Sub-Saharan Africa: Identifying SME Roles and Obstacles to SME Growth. MENON Business Economics, MENON Publication No. 14/2010.

Fuglsang, L., \& Olsen, P. B. (Eds.) (2004). Theory of Science in the Social Sciences. Across Professional Cultures and Paradigms, 2nd Greatly Expanded Edition (2 ed.). Roskilde: Roskilde Universitetsforlag.

Gerber, E. M., Hui, J. S., \& Kuo, P.-Y. (2012). Crowdfunding: Why People Are Motivated to Post and Fund Projects on Crowdfunding Platforms. Proceedings of the International Workshop on Design, Influence, and Social Technologies: Techniques, Impacts and Ethics, 2, 11. 
GLOBAL, E. M. (2018). Global Report 2017-2018. In Global Entrepreneurship Research Association (GERA).

https://www.gemconsortium.org/report/gem-2017-2018-global-report

Ibrahim, N. (2012). The Model of Crowdfunding to Support Small and Micro Businesses in Indonesia through a Web-Based Platform. Procedia Economics and Finance, 4, 390-397. https://doi.org/10.1016/S2212-5671(12)00353-X

Kamunge, M. S., Njeru, A., \& Tirimba, O. I. (2014). Factors Affecting the Performance of Small and Micro Enterprises in Limuru Town Market of Kiambu County, Kenya. International Journal of Scientific and Research Publications (IJSRP), 4, 1-20.

Kauffmann, C. (2005). Financing SMEs in Africa (7). https://ideas.repec.org/p/oec/devaac/7-en.html

Kithae, P. P., Gakure, R. W., \& Munyao, L. M. (2012). The Place of Micro and Small Enterprises in Kenya in Achievement of Kenya's Vision 2030. Journal of US-China Public Administration, 9, 1432-1440.

Massolution (2015). 2015 CF: The Crowdfunding Industry Report 2015.

Mollick, E. (2014). The Dynamics of Crowdfunding: An Exploratory Study. Journal of Business Venturing, 29, 1-16.

https://doi.org/https://doi.org/10.1016/j.jbusvent.2013.06.005

Mwarari, M. M., \& Ngugi, P. K. (2013). Factors Influencing Listing of Kenyan SMEs in the Securities Market for Capital Raising Opportunities. European Journal of Management Sciences and Economics, 1, 99-115.

Rau, P. R. (2017). Law, Trust, and the Development of Crowdfunding. SSRN Electronic Journal, (May). https://doi.org/10.2139/ssrn.2989056

Samarah, W. E. A. R., \& Alkhatib, S. F. S. (2019). Crowdfunding Operations: Outreach Factors in Developing Economies. Journal of Public Affairs, 20, e1988.

https://doi.org/10.1002/pa.1988

Savarese, C. (2015). Crowdfunding and P2P Lending: Which Opportunities for Microfinance? EMN MAGAZINE, (May).

Wardrop, R., Zhang, B., Rau, R., \& Gray, M. (2015). Moving Mainstream: The European Alternative Finance Benchmarking Report. Cambridge: Cambridge Centre for Alternative Finance. http://www.jbs.cam.ac.uk/index.php?id=6481\#.VTOtICGqpBd 